\title{
INVESTIGATING THE CONTRIBUTORS TO BRAND LOYALTY WITH A MEDIATING ROLE OF SATISFACTION: EVIDENCE FROM PAKISTAN
}

\section{Tooba $\operatorname{Irfan}^{1}$ and Misha Siddiqui ${ }^{2}$}

\begin{abstract}
This study aims to test the empirical impact of the image of the brand, customer satisfaction and product \& service quality on brand loyalty in territories of Pakistan. This study is applied research-based however there are many previous research studies related to the topic, but this research is different and unique as the data in this research is taken from the developing economy of Pakistan where there is a sharp dearth of these types of research investigations. The data was collected through secondary authentic sources. Moreover, the sample size of the study is 300. The data was analyzed through statistical softwares such as SPSS, AMOS and SMART PLS. The results indicate that there is a relationship linking brand awareness and brand loyalty with buying behaviour of the customer along with the mediation effect of sales promotion. The research is supported by descriptive analysis. This study is pervasive in nature as it enhances knowledge on the subject to help organizations, brand management and other related institutions.
\end{abstract}

Keywords: Brand Image; Brand Trust; Service Quality; Brand Loyalty; Customer Satisfaction.

\section{INTRODUCTION}

Brand every so often held functional component as well as emotional one. Mostly marketing strategies focus on value creation and relationship (Iglesias, Singh, \& Batista-foguet, 2011). Well, Alam, and Nor (2011), described that the brand purchase occurrence is related to loyalty for brand, and state that those who have intention to purchase again from the same brand, they are the brand

\footnotetext{
${ }^{1}$ KASBIT, Karachi, Pakistan

${ }^{2}$ KASBIT, Karachi, Pakistan
} 
loyalists and they must have some emotional attachment or commitment for the brand from where they purchase again. Loyalty relies mostly on knowledge of marketing. Loyalty of brand is a broad subject of research. The loyalty concept comes from literature of the customer behavior (Chegini, 2011). From the last few decades, loyalty of brand in marketing literature is considered to be the most important and valuable factors to the marketers (Nawaz \& Usman, 2011). In every organization, the customers are considered to be the most valuable constituents, and they should be treated well. It is emphasized that the customer considerations should be properly managed and handled too. Customers will definitely be satisfied when their expectations, needs and wants are fulfilled. Satisfied customers endure loyalty towards the brand, repurchase, show positivity toward their satisfactory brand and speak good words for the organization (Brown, Churchill, \& Peter, 1992) . This satisfaction also creates a chain of WOM. The satisfactions of customers mostly specify the response of the customer to the condition of fulfillment and the redresses the customer opinions (Oliver, 1997).

A brand is usually determined as the symbol, name, design or sign and combination of them, the aim of the brand is to provide the identification of a specific seller and differentiate them from competitor (Keller, 1993). To obtain the long-term benefits, it is required to create or keep the faithful customers, but it is quite difficult to do so in today's competitive environment. Brand loyalty is based on repeat purchase of any customer that reflects his or her conscious decision to continuously purchase from the loyal customer that shows the intentional decision of the customer to again purchase. Through this organizations gauge the positive attitude of the loyal customer towards the brand that is presumed to re-purchase the product in future. It is not all about purchasing the product repeatedly, but it is also an intellectual commitment of the loyal customer towards the brand. There are so many promotional techniques including brand image, promotion and brand positioning that make place in the mind of the customers (Rehman, Zia-Ur-Rehman, \& Akhtar, 2012). Every marketer wants to maintain long-term and good relationship with their customers especially in times when so many competitors exist in the competitive business world. Singh (2016) stated that the loyalty of the brand is not anything but to provide complete satisfaction to the customers. The word satisfaction means trust, belief, and faith on a specific brand where so many brands exist with so many products, but you satisfy with the specific one (Singh, 2016). The competitive world pressurize the organizations maintaining that their target is not only to sale the 
products or provide services to your customers, but also keep good relationship with customers for long-term so that the loyal customers towards the brands could be retained (Doostar, Asil, \& Behrang, 2013).

Furthermore, in this essence, Well, Alam and Nor (2011), stated that the loyalty of the brand is a result of attitude and behavior. Without bearing these aspects in mind, the action of repeat purchase does not support enough towards the loyalty of the brand. The marketers accentuate this influential factor emphasizing that the loyalty of the brand help to decrease the cost of performing business, thus marketers have to improve the organization's profitability as well as brand worth. Satisfaction of the customer is most important part of marketing as customer consciousness has already resulted in inflated competition and has encouraged marketers to build up good and long-term relationships with customers. The customer centricity is considered to be the most important factor of the longterm business sustenance and success (Li \& Chaipoopirutana, 2016; Kinuthia, Keren, Burugu, Muthomi, \& Mwihaki, 2012). Ehsani and Ehsani (2015) considered commitment of the customer to be a crucial and precious asset for the organizations. Moreover, Ramiz, Qasim, Rizwan, Aslam, and Khurshid (2014), stated that the loyalty of the brand is the frame of mind when the customer is prepaid to pay further for a specific brand. The product branding is the most important factor to get the loyal customer and it also effects to shape the buying intention. Most of the mangers accept that customers need to get branded products is important as they consider this vital to be associated with the certain group of people (Shehzad \& Zehra, 2013).

The aim of this research to study the factors that determine the loyalty of a brand and investigate the importance of the factors such as brand trust, image, and customer satisfaction. As in the current modern era, technology changes rapidly and through this mass manufacturing is implied. It is thus essential to understand the buying behavior of the customer through social media. Furthermore, in Pakistan the benefits of the marketing efforts of different brands are different from the rest of the globe due to its unique and complex markets and socio-economic disparities.

Thus, the main reason to perform this research is to determine the area of loyalty towards brand in the mobile phone industry and its progress in markets. It has been observed that the customer wants, and expectations are rapidly changing in the mobile phone industry, and it will continuously change due to new innovative inventions and advancements in the level of technology. The users 
of mobile phone are largely young generation, so it is necessary to attract the new generation by new innovation and modern technologies, features and design and to gain profit by making them faithful and loyal. In this research, variables like brand trust, and brand image are examined and service quality as a mediation of customer satisfaction is taken which is perceived to impact brand loyalty.

\section{STATEMENT OF THE PROBLEM}

In the fast-paced changing global trends, thousands of brands are active and implement innovative strategies to obtain new customers and to retain the existing pool. The world full of competition where customers have wider access to knowledge about alternatives, have opportunity of acquiring vast knowledge, and access to awareness of the products and services, it is complicated for the marketers in the organizations to prevent customers from shifting towards alternative brands. It is equally challenging for marketers to build brand loyalty and it is not easy to find the elements which should be concentrated to attract customers and make them loyal toward brands (Tabish, Hussain \& Saher, 2017).

\section{RESEARCH QUESTIONS}

- This research emphasizes to answer following research questions.

- Does the brand image impact the customer satisfaction?

- Does the brand trust impact customer satisfaction?

- Does the o service quality impact customer satisfaction?

- Does the image of the brand impact brand loyalty?

- Does the trust of the brand impact brand loyalty?

- Does the services quality impact brand loyalty?

- Does customer satisfaction meditate the relation between brand loyalty and service quality?

- Does customer satisfaction meditate the relation between brand loyalty and brand image?

- Does customer satisfaction meditate the relation between brand loyalty and brand trust?

\section{THEORETICAL FRAMEWORK}

The image of the brand is one of the essential factors for marketers. It possibly and powerfully influences the preferences of customer to present their image. With the help of the product's possessions which they already have they define their own self (Tsai-Yuan \& Min-Yen, 2013). 
The image of the brand is the presentation of the brand in the mind of the customer .Studies postulate that the product image can be classified into the three images that are perceived, social and functional. The brand trust is one of the major valuable factors of the brand loyalty (Well, Alam, \& Nor, 2011). If the customer receives the best quality product and the product according to their expectations, they will definitely pay more to get the product from the brand. The brand that fulfills the customers' expectations due to its uniqueness creates customer loyalty (Ramiz, Qasim, Rizwan, Aslam, \& Khurshid, 2014). The brand loyalty creation has two common approaches. The first approach is the behavioral concern which have some innate characteristics that develop brand trust which in turn is reviewed as the most valuable element that develops beneficial relationships between the customers and the brand. The literature of the loyalty has divulged that for customer seek product durability, better services and better consumable products. Loyalty must be calculated differently because overall market agents have dissimilar approaches (Lovelock, Patterson, \& Walker, 1998). This study focuses on cellular network industry as the providers of cellular network confront soaring saturation. Thus, the marketers contemplate that is the most attractive and outstanding sector for which the related firms need to act responsible and perform considerably towards the service users (Kuusik, 2007). Similarly, most of the scholars accept as true that the satisfaction of the customer is the most vital elements that impact on the loyalty of brand.

\section{RESEARCH MODEL}

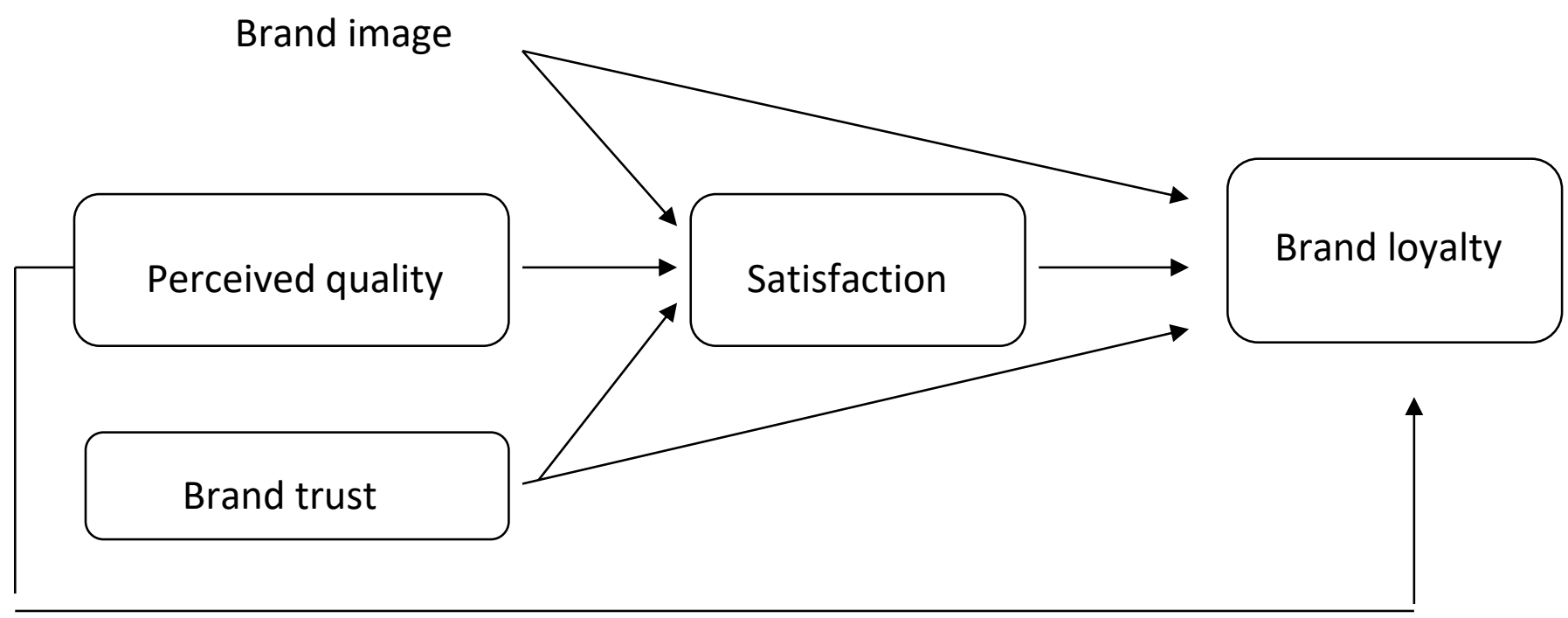




\section{RESEARCH HYPOTHESIS}

H1: Brand Image has an impact on satisfaction.

H2: Brand Image positively influence Brand loyalty.

H3: Service quality positively effect satisfaction.

H4: Service quality positively influence brand loyalty.

H5: Brand trust impacts satisfaction.

H6: Brand trust has a positive effect on Brand loyalty.

H7: Satisfaction has a positive influence on brand loyalty.

\section{LITERATURE REVIEW}

\section{Brand Loyalty}

The concept of brand loyalty began in 1920 (Bennett, 2001). Brand loyalty is defined as "the discrimination of behavioral response at the time of purchase and expression of decision-making with observation of one or more different substitute brands". It is deemed to be a purpose of intellectual and mental processes (Jacoby, 1971). Fournier and Yao (1977) stated the focus of any organization is the evaluation and maintenance of the loyalty of brand toward the customers. The factor is specifically observed in markets with low product differentiation, severe competition and extreme unpredictability.

\section{Brand Image}

In customers mind, brand image is described as a symbol which contributes to forming and linking the customers perception about the brand (Cretu \& Brodie, 2007). It also described as a picture in customer's mind about brand and also represents the qualities of goods and services offered by the brand (Salinas \& Perez, 2009).

\section{Service Quality}

There are two classifications through which customers depend on brands to form an opinion based on quality. Initial intrinsic brands describe the physical qualities of products, whereas the extrinsic brands do not include in physical products and can also be analytically managed without altering 
the physical attributes of products (Szybillo \& Jacoby, 1974). Brand quality concern create ambiguity in the mind of customers, customers depend on external suggestion for example design of product, brand name, advertisement, and packaging to understand the form of quality of brand (Kirmani \& Rao, 2000). In this sense, quality of service is not actual quality and real performance of a service or product. Instead, the overall product is subjective of customer appraisal (Zeithaml, 1988).

\section{Satisfaction}

Satisfaction is defined as customer fulfillment with respect to purchases with a organization (Christodoulides \& Michaelidou, 2011; Anderson \& Srinivasan, 2003). To satisfy the customer or formation of purchasers who are happy and satisfied to organizations are the biggest concerns in management (Veloutsou, Gilbert, Moutinho, \& Goode, 2005). Generally, satisfaction is a fulfillment of response, judgment, focused on a good and service and estimate for a single time or continuous consumption (Oliver, 1977).

\section{Brand Image's Impact on Satisfaction and Brand Loyalty}

In different sectors such as cell phones, retail and supermarkets, banking/e-banking, the image of the trademark renders customer satisfaction through trust (Gronholdt, Martensen, \& Kristensen, 2000). Chang and Tu (2005) recommended that infrastructure of a store, store assistance, its comfort and sales campaigns are the four main elements of store profile, and they eventually lead directly to customer fulfillment. Chitty, Ward, and Chua (2007) proved that trademark image has a dominant part in forecasting fulfillment of customer in hospitality industry. Additionally, Jamal and Goode (2001) suggested that there is a parallel link between trademark image and self-image which may grow customer fulfillment. Torres and Bijmolt (2009), claim that trademark image in general, sends out signals to customers to make them believe at a certain brands which help in forming a purchase decision.

Marketers imagine brand image essential through which the quality of services and goods is assessed by the customers and this is contemplated as product hint (Cretu \& Brodie, 2007) Moreover, brand image reflect the functions, characteristics, and promising quality of products and services which help customers to envision their self-perception that results in reaching purchase decision (Aghekyan-Simonian, Forsyth, Kwon, \& Chattaraman, 2012). Wood (2004) stated that good branding is a result of the image of the brand which mostly use to highlight the 
services and products and when the image represents the brand to the customers, they comprehend the brand in a better way (Morgan \& Hunt, 1994).

\section{Service Quality's impact on Satisfaction and Brand Loyalty}

The relationship between satisfaction and service quality is robust (Olsen, 2002). Most the of marketing researchers and interpreters accept the reality that quality helps to establish customer satisfaction (Oliver, 1977; Dabholkar, Shepherd, \& Thorpe, 2000). According to Olsen (2002) the performance of quality and satisfaction effect the brand likeness of the customers. Quality of service also helps organization to maintain their quality standards as well as impact the loyalty of customer. Aaker (1991) stated that evaluation of product quality creates competition, and build brand perceptions, hence, superior perception provide better satisfaction and that ultimately enhances brand loyalty.

\section{Brand trust impact on Satisfaction and Brand Loyalty}

The effect of customers satisfaction on the loyalty of brand has been an significant study subject. Different studies propose the direct relation between the brand loyalty and customer satisfaction and emphasize that the satisfaction of the customers brings complete loyalty towards the brand and if the customer is dissatisfied with the brand it create problem for the brand that customer will definitely shift towards the other brands. After gauging diverse factors which include brand loyalty many researchers observed that the customer satisfaction and brand loyalty a positive and strong relationship (Li \& Chaipoopirutana, 2016). They found out that the customer satisfaction make better reputation in the marketplace and reputation intercede the relation of satisfaction of the customer and loyalty towards brand. If the customer's expectations are fulfilled by the brand's quality, uniqueness and its functions so the loyal customer would pay more to get the branded product because that specific brand provide them comprehensive attributes which the customer required, and that other brand cannot provide. Researcher have found that the brand trust is the most important variable that maintain the long-lasting relationship and to meet up the value that customer desired for (Well, Alam, \& Nor, 2011). Most of the scholars accept that satisfaction of the customer is one of necessary components which impact brand loyalty.

\section{Customer Satisfaction and Brand Loyalty Relationship}

There is vast data available in literature which indicates that the brand loyalty is directly affected by dissatisfaction and satisfaction of purchasers. Therefore, utilizing the evidence it may be said 
that satisfaction is a powerful driver of brand loyalty (Lim, Widdows, \& Park, 2006; Anderson \& Sullivan, 1993; Zeithaml, Berry, \& Parasuraman, 1996). When customers are likely to repeatedly purchase same goods and services, it reflects their satisfaction (Johnson, Gustafsson, Andressen, Lervik, \& Cha, 2001).

\section{RESEARCH METHODOLOGY}

The research technique used in this research paper is quantitative. This method of research collects a large number of data and follows a quantitative system, in which data is analyzed with the help of statistical models, showing the relationships and associations among the studied variables. Quantitative approach is the business research that addressees research objective through empirical assessment that involve numerical measurement and analysis (Zikmond, Babi, Carr, \& Griffin, 2010). The major objective of this study is to find correlations. In this study, researchers find the relation between brand trust, brand image and service quality on brand loyalty by adding mediation that is customer satisfaction.

\section{STATISTICAL TESTING}

\section{Construct Reliability}

Table 1. Construct Relibility and Validity

\begin{tabular}{lllll}
\hline & $\begin{array}{l}\text { Cronbach's } \\
\text { Alpha }\end{array}$ & rho_A & $\begin{array}{l}\text { Composite } \\
\text { Reliability }\end{array}$ & $\begin{array}{l}\text { Average Variance } \\
\text { Extracted (AVE) }\end{array}$ \\
\hline BRAND IMAGE & 0.899 & 0.907 & 0.937 & 0.832 \\
BRAND LOYALTY & 0.859 & 0.874 & 0.907 & 0.713 \\
BRAND TRUST & 0.983 & 0.983 & 0.989 & 0.967 \\
SATISFACTION & 0.833 & 0.862 & 0.896 & 0.743 \\
SERVICE QUALITY & 0.944 & 0.95 & 0.957 & 0.817 \\
\hline
\end{tabular}

Source: Study Analysis

The acceptable value of Cronbach's alpha, rho_A, composite reliability is $70 \%$ more than $80 \%$ so the data of consistency is accurate and reliable (Taber, 2017). So as in above mention that the value of Cronbach's alpha is 0.899 brand image, 0.859 brand loyalty, 0.983 brand trust, 0.833 satisfaction and 0.944 service quality and according to standardized value of rho_A and composite reliability is above than 0.70 and average variance extracted (AVE) should be more than 0.50 so as mentioned in table no. 1 brand loyalty, brand trust, brand image, satisfaction and service quality showed the standardized value. 
Table 2. Discriminant Validity: Fornell Larcker

\begin{tabular}{|c|c|c|c|c|c|c|}
\hline & $\begin{array}{l}\text { Brand } \\
\text { Image }\end{array}$ & $\begin{array}{l}\text { Brand } \\
\text { Loyalty }\end{array}$ & $\begin{array}{l}\text { Brand } \\
\text { Trust }\end{array}$ & Satisfaction & & $\begin{array}{l}\text { Service } \\
\text { Quality }\end{array}$ \\
\hline Brand Image & 0.912 & & & & & \\
\hline Brand Loyalty & 0.644 & 0.845 & & & & \\
\hline Brand Trust & 0.34 & 0.616 & 0.983 & & & \\
\hline Satisfaction & 0.389 & 0.703 & 0.791 & & 0.862 & \\
\hline Service Quality & 0.554 & 0.404 & 0.645 & & 0.517 & 0.904 \\
\hline
\end{tabular}

According to table 2. the validity of each variable and discrimination of the data the AVE square root value is more than the value of diagonal and should be more than off diagonal value (Fornell $\&$ Larcker, 1981), and also proved that model of every variable does not equivalent to each other.

Table 3. Heterotrait Monotrait Ratio

\begin{tabular}{|c|c|c|c|c|c|}
\hline & $\begin{array}{l}\text { Brand } \\
\text { Image }\end{array}$ & $\begin{array}{l}\text { Brand } \\
\text { Loyalty }\end{array}$ & $\begin{array}{l}\text { Brand } \\
\text { Trust }\end{array}$ & Satisfaction & $\begin{array}{l}\text { Service } \\
\text { Quality }\end{array}$ \\
\hline \multicolumn{6}{|l|}{ Brand Image } \\
\hline Brand Loyalty & 0.721 & & & & \\
\hline Brand Trust & 0.36 & 0.695 & & & \\
\hline Satisfaction & 0.44 & 0.825 & 0.811 & & \\
\hline Service & 0.596 & 0.464 & 0.668 & 0.533 & \\
\hline Quality & & & & & \\
\hline
\end{tabular}

Ringle, Silva and Bido (2014) explained that the value of HTMT lower than 0.80 to 0.85 and the value of these variables' relation are discriminate to each variable and does not equivalent to other one and proved their validity. The outcome of table no. 4 value are equivalent to HTMT relationship of every variable is lower than 0.8 to 0.85 . The latent variable of discrimination is showing the reliability and consistency. The result show that all value of variable in the middle of 0.80 to 0.85 so they are reliable, and every variable discriminate with other one.

Table 4. R-Square

\begin{tabular}{lrc}
\hline & R Square & R Square Adjusted \\
\hline Brand Loyalty & 0.705 & 0.7 \\
Satisfaction & 0.646 & 0.641
\end{tabular}

The table (4) indicates that the R square value is $2 \%$ more than or lower than $2 \%$ is poor and the $13 \%$ is better value of R Square and value of $26 \%$ are good and the variance value effect on independent variables (Cohen, 1988). The independent variable are related with the dependent variable, the high value show that in model there is no such variation. 
Table 6. Path Coefficient

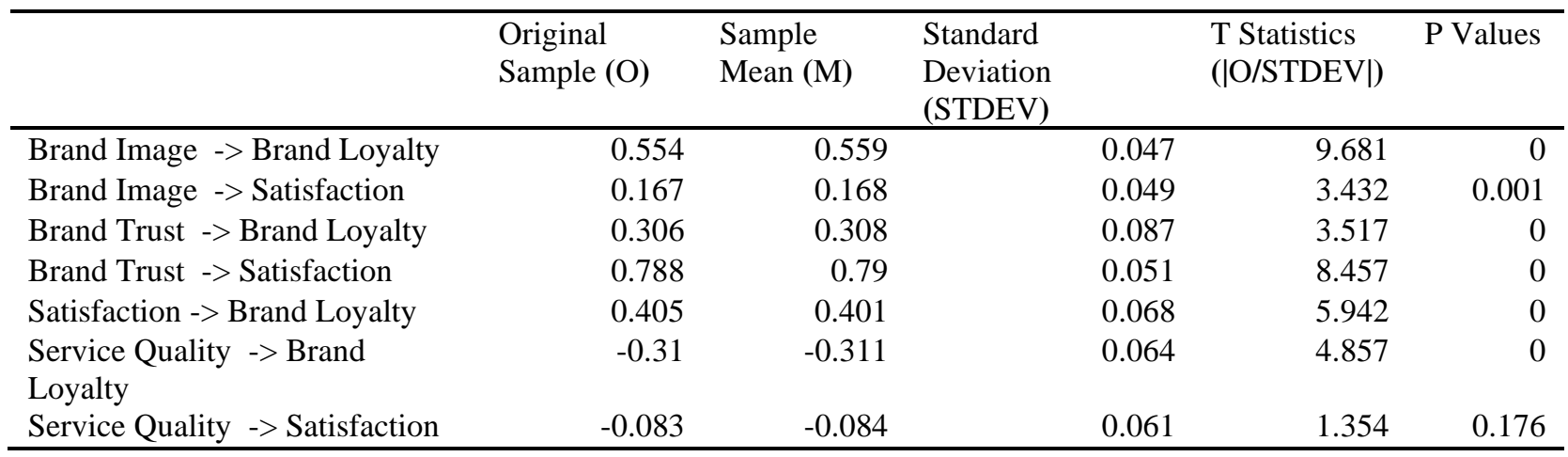

Table 6 provides the significant value of $\mathrm{P}$-value, $\mathrm{T}$ statistics to indicate the independent variable to dependent variable. The value of acceptance is (+/-2) more than and value of $\mathrm{P}$ should be more than 0.05 and dismiss (fail) the null hypothesis (Hult, et al., 201). On the basis of results, all values are significant but the last $\mathrm{p}$ and $\mathrm{t}$ value service quality with satisfaction are rejected.

\section{DISCUSSION AND CONCLUSION}

This research deliberates to investigate the element that impacts the loyalty of brand in the industry of mobile phone. The study of this research we identify the relationship between mediation and dependent variable like calculate the effect of customer satisfaction from brand loyalty. The software we use in the research paper is smart pls. The main precursor for the model selected includes brand image, service quality, customer satisfaction and brand trust. Their affiliation and connection to brand loyalty give extensively of the stand-in study. This study major key findings include the acquiring of hypothesis and the propound model. The results first outcome is to better service quality of the present service and attentive to services which create the loyalty towards the brand. Normally in the industry of mobile phone and accurately in service sector, service quality is a great deal (Santouridis \& Trivellas, 2010) most of the studies prove the connection that level the satisfaction of the customer is based of service quality. Furthermore, it has an interceding impact on brand loyalty and service quality (Aydin \& Oze, 2005); (Santouridis \& Trivellas, 2010). The sign strong Favorable notable relationships corroborate through other results of the study (Delgado Ballester \& Munuera Aleman, 2001).

The difference arises due to the areas under the study (the study area is B2B sector). The result of this research shows that the brand loyalty and brand trust are ideational attach and have a 
completely positive relationship. The study supported the hypothesis manage on Turkish mobile network (Aydin \& Oze, 2005) to sum up the conversation, it could be ended that the brand image, satisfaction, service quality, brand trust are major precursor of the loyalty of the brand for the industry of mobile phone sector and for the other alike markets. The most important factor is the service quality that directly impact on customer loyalty. All null hypotheses are failed to reject. There is a long-term relationship between all independent variable brand image, service quality and brand trust from dependent variable like brand loyalty and positive impact on DV. And also, mediation customer satisfaction impact positively the brand loyalty. 


\section{REFERENCES}

Aaker, D. A., \& Equity, M. B. (1991). Capitalizing on the Value of a Brand Name. New York, 28(1), 35-37.

Accenture, J. A., \& Advani, J. Y. (2005). Factors Affecting Brand Loyalty: A study in an emerging markets on fast moving consumer goods.(II Banglore, Ed.). Journal of customer behaviour.

Aghekyan-Simonian, M., Forsythe, S., Kwon, W. S., \& Chattaraman, V. (2012). The role of product brand image and online store image on perceived risks and online purchase intentions for apparel. Journal of Retailing and Consumer Services, 19(3), 325-331.

Anderson, E. W., \& Sullivan, M. W. (1993). The antecedents and consequences of customer satisfaction for firms. Marketing science, 12(2), 125-143.

Anderson, E. W., Fornell, C., \& Mazvancheryl, S. K. (2004). Customer satisfaction and shareholder value. Journal of marketing, 68(4), 172-185.

Anderson, R. E., \& Srinivasan, S. S. (2003). E-satisfaction and e-loyalty: A contingency framework. Psychology \& marketing, 20(2), 123-138.

Aydin, S., \& Özer, G. (2005). The analysis of antecedents of customer loyalty in the Turkish mobile telecommunication market. European Journal of marketing.

Bennett, R. (2001). A Study of Brand Loyalty in the Business-to-Business Services Sector.

Brown, T. J., Churchill, G. A., \& Peter, J. P. (1992). Improving the measurement of service quality; School of Business, University of Wisconsin-Madison.

Chang, C., \& Tu, C. (2005). Exploring Store Image, Customer Satisfaction and Customer Loyalty Relationship: Evidence from Taiwanese Hypermarket Industry. Journal of American Academy of Business , 7, 197-202.

Chegini, M. (2011). Customer Loyalty and Value Key Dimensions Interaction in Organization. China-USA Business Review, 9(8), 8-14.

Chitty, B., Ward, S., \& Chua, C. (2007). An Application of the ECSI Model as a Predictor of Satisfaction and Loyalty for Backpacker Hostels. Marketing Intelligence \& Planning , 25, 563-580.

Christodoulides, G., \& Michaelidou, N. (2011). Shopping motives as antecedents of e-satisfaction and e-loyalty. Journal of Marketing Management , 27(1/2), 181-197. 
Cohen, J. (1988). Statistical power analysis for the behavior science: Lawrance Eribaum association.

Cretu, A., \& Brodie, ,. R. (2007). The influence of brand image and company reputation where manufacturers market to small firms: a customer value perspective. (Vol. 2). (36, Ed.) Industrial Marketing Management.

Dabholkar, P., Shepherd, C., \& Thorpe, D. (2000). A Comprehensive Framework for Service Quality: An Investigation of Critical Conceptual and Measurement Issues Through a Longitudinal Study. Journal of Retailing , 76(2), 139-73.

Delgado Ballester, E., \& Munuera Aleman, J. L. (2001). Brand trust in the context of consumer loyalty. European Journal of Marketing , 35(11/12), 1238-1258.

Doostar, M., Asil, S., \& Behrang, N. (2013). Factors and elements influencing brand loyalty: A case study in customers of Khazargaz in Mazandaran. International Journal of Agriculture and Crop Sciences , 6(12), 712.

Ehsani, Z., \& Ehsani, M. (2015). Effect of quality and price on customer satisfaction and commitment in Iran auto industry. International Journal of Service Science, Management and Engineering , 1(5), 52.

Fornell, C., \& Larcker, D. F. (1981). Structural equation models with unobservable variables and measurement error: Algebra and statistics.

Fournier, S., \& Yao, J. (1977). Reviving brand loyalty: a reconceptualization within the framework of consumer-brand relationship. International Journal of Marketing , 14, 451 -473.

Gronholdt, L., Martensen, A., \& Kristensen, K. (2000). The Relationship between Customer Satisfaction and Loyalty: Cross-Industry Differences. Total Quality Management. 11, 509514.

Hult, G. T. M., Hair Jr, J. F., Proksch, D., Sarstedt, M., Pinkwart, A., \& Ringle, C. M. (2018). Addressing endogeneity in international marketing applications of partial least squares structural equation modeling. Journal of International Marketing, 26(3), 1-21.

Iglesias, O., Singh, J., \& Batista-foguet, J. (2011). The Role of Brand Experience and Affective Commitment in Determining Brand Loyalty. 18 (8), 570-582.

Jacoby, J. (1971). A model of multi-brand loyalty. Journal of Advertising Research, 11(3), 25-61. 
Jamal, A., \& Goode, M. (2001). Consumers and Brands: A Study of the Impact of Self-Image Congruence on Brand Preference and Satisfaction. Marketing Intelligence \& Planning , 19, 482-492.

Johnson, M., Gustafsson, A., Andressen, T., Lervik, L., \& Cha, J. (2001). The evolution and future of national customer satisfaction index models. Journal of Economic Psychology , 22(2), 217-245.

Keller, K. L. (1993). conceptualizing, measuring and managing customer-based brand equity. The Journal of Marketing, 1-22.

Kinuthia, L., Keren, G., Burugu, M., Muthomi, H., \& Mwihaki, M. (2012). Factors influencing brand loyalty in sportswear among Kenyan university students: the case of swimmers. Differences, (1).

Kirmani, A., \& Rao, A. R. (2000). No pain, no gain: A critical review of the literature on signaling unobservable product quality. Journal of marketing, 64(2), 66-79.

Kuusik, A. (2007). Affecting customer loyalty: Do different factors have various influences in different loyalty levels?. The University of Tartu Faculty of Economics and Business Administration Working Paper, (58-2007).

Li, Z., \& Chaipoopirutana, A. P. (2016). The Important Factors that influence on Building brand Loyalty Towards Chang'Ancar Brand in Xi'an City, Shaanxi, China.

Lim, H., Widdows, R., \& Park, J. (2006). M-loyalty: winning strategies for mobile carriers. Journal of Consumer Marketing , 23(4), 208-218.

Lovelock, C. H., Patterson, P. G., \& Walker, R. H. (1998). Services Marketing. Sydney: Prentice Hall.

Morgan, R., \& Hunt, S. (1994). The commitment-trust theory of relationship marketing. Journal of Marketing , 58(3), 20-38.

Nawaz, N., \& Usman, A. (2011). What Makes Customers Brand Loyal: A Study on Telecommunication Sector of Pakistan. International Journal of Business and Social Science, 5(2), 213-221.

Oliver, R. (1977). Satisfaction: A Behavioral Perspective on the Consumer.

Olsen, S. (2002). Comparative Evaluation and the Relationship Between Quality, Satisfaction, and Repurchase Loyalty. Academy of Marketing Science , 30 (3), 240-249. 
Ramiz, M., Qasim, M., Rizwan, M., Aslam, F., \& Khurshid, ,. A. (2014). The Comparative Analysis of the Factors Effecting Brand Loyalty towards Samsung Products. Journal of Sociological Research , 5(1), 327-349.

Rehman, A., Zia-Ur-Rehman, M., \& Akhtar, W. (2012). Factor affecting brand loyalty: a perspective of fast-food restaurants Actual Problems of Economics. (130), 13-20.

Ringle, CM, Da Silva, D., \& de Souza Bido, D. (2014). Structural equation modeling using SmartPLS. Revista Brasileira de Marketing , 13 (2), 56-73.

Salinas, E., \& Perez, J. (2009). Modeling the brand extensions' influence on brand image. (Vol. 62). (1, Ed.) Journal of Business Research.

Santouridis, 1., \& Trivellas, P. (2010). Investigating the impact of service quality and customer satisfaction on customer loyalty in mobile telephony in Greece. The TQM Journal , 22(3), 330-343.

Shehzad, A., \& Zehra, M. (2013). Factors Influencing the Cell Phone Brand Loyalty of Swedish Generation Y. 56.

Singh, R. (2016). Factors Affecting Brand Loyalty In The Footwear industry-A Study Of Ludhiana District.

Szybillo, G. J., \& Jacoby, J. (1974). Intrinsic versus extrinsic cues as determinants of perceived product quality. Journal of Applied Psychology, 59(1), 74.

Taber, K. S. (2017). Reflecting the nature of science in science education. In Science Education (pp. 21-37). Brill Sense.

Tabish, M., Hussain, S. F., \& Afshan, S. (2017). Factors that affect brand loyalty: A study of mobile phone industry of Pakistan. KASBIT Business Journal (KBJ), 10, 151-170.

Torres, A., \& Bijmolt, T. (2009). Assessing brand image through communalities and a symmetries in brand-to-attribute and attribute-to-brand associations. European Journal of Operational Research , 195(2), 628-640.

Tsai-Yuan, L., \& Min-Yen, C. (2013). A study of the factors that influence the brand loyalty of Taiwanese adolescents with respect to purchasing mobile.The case of Taichung City. Problems and Perspectives in Management, 11(2).

Veloutsou, C., Gilbert, R., Moutinho, L., \& Goode, M. (2005). Measuring transaction specific satisfaction in services are the measures transferable across cultures. European Journal of Marketing , 39(1/2), 606-628. 
Wel, C. A. B. C., Alam, S. S., \& Nor, S. M. (2011). Factors affecting brand loyalty: An empirical study in Malaysia. Australian Journal of Basic and Applied Sciences, 5(12), 777-783.

Well, C., Alam, S., \& Nor, S. (2011). Factors Affecting Brand Loyalty: An Empirical Study in Malaysia. Australian Journal of Basic \& Applied Sciences, 5(12).

Wood, L. (2004). Dimensions of brand purchasing behaviour: consumers in the 18-24 age group. Journal of Consumer Behaviour , 4(1), 9-24.

Zeithaml, V. (1988). Consumer perceptions of price, quality, and value: A means-end model and synthesis of evidence. Journal of marketing , 52(3), 2-22.

Zeithaml, V., Berry, L., \& Parasuraman, A. (1996). The behavioral consequences of service quality. Journal of Marketing , 60 (2), 31-46.

Zikmond, W., J.Babi, B., C.Carr, J., \& Griffin, M. (2010). Business Research Methods. (9th, Ed.). 